\title{
Impacts of Policy and Legal Framework on Sustainable Forest Governance in Ethiopia
}

\author{
Alemayehu N. Ayana \\ Ethiopian Environment and Forest Research Institute, \\ P. O. Box 24536 Code 1000, Addis Ababa, Ethiopia
}

\begin{abstract}
s
Forest resources in Ethiopia provide multiple goods and services including food, medicine, energy, shelter, clean water, land stabilization, erosion control, maintaining biodiversity, and regulation of climate change. However, these resources have been facing numerous challenges and are increasingly under threat for quite a long time. This study adopted the Governance of Forests Initiative (GFI) framework to assess the impacts of policies and legal framework on sustainable forest governance in Ethiopia. The GFI framework is a comprehensive tool used to diagnose and assess strengths and weaknesses of legal and policy arrangement governing forestry sector. Ethiopia has formulated and implemented various forest policies and legal instruments to address the persistent challenges of sustainable forest management and to fulfill the economic and societal benefits expected from the sector. However, our analysis shows a huge gap between legal and policy design and implementation. The existing efforts have focused on developing policy and legal instruments, while little has been done to implement them at the local level. Implementation instruments such as regulations, directives and guidelines have not sufficiently developed to translate the broader policy intents into practice. Lack of proper implementation instruments not only undermine forest management but also hinder national efforts to halt deforestation and achieve the country's ambitious plan for fast and sustainable development. Therefore, it is crucial to translate policy and legal provisions regarding forest governance into implementation instruments such as regulations, directives, and guidelines. Accurate and up-to-date information and records that contain comprehensive legal and spatial information about forest conservation areas should be maintained centrally both at regional state and federal level and freely accessible by the public.
\end{abstract}

Keywords: policy impact; legal framework; Governance of Forests Initiative; implementation, forest governance; Ethiopia

DOI: $10.7176 / \mathrm{JESD} / 11-5-03$

Publication date:March $31^{\text {st }} 2020$

\section{Introduction}

Ethiopia is an agrarian developing country and its economy largely depends on agriculture and extraction of renewable natural resources. Forests are one of the vital renewable resources that support the livelihoods of millions of people. They provide a wide range of goods and eco-system services including food, medicine, energy, shelter, clean water, land stabilization, erosion control, maintaining invaluable biodiversity by providing critical habitat for flora and fauna, and regulation of climate change. Despite its significant role, Ethiopia has experienced multiple challenges in managing its forest and related environmental resources for quite a long time. These challenges are associated with poor legal and institutional framework, which resulted in considerable loss of the country's forest cover, topsoil, bio-diversity resources, and emission of GHG (Green House Gas). Currently, Ethiopia has about 17.35 million hectares of forests (15.7\% of the country area), which include bamboo, dense woodland, natural forests, and planted forests.Forest resources in Ethiopia are under threat with net annual loss of 72,000 ha or deforestation rate of $0.54 \%$ from 2000 to 2013 (Ethiopia's FRL-revised submission to UNFCCC, 2016). Several studies show that this alarming rate of deforestation will not only damage valuable ecological services but also impair the rural development efforts and livelihoods of forest dependent communities. Factors that contributed for deforestation and forest degradation include absence of comprehensive land use planning;institutional instability and low capacity of forestry institutions; poor inter-setoral coordination and lack of synergy between sectors, inadequacy of the forestry legal framework and weak law enforcement, and unclear tenure and forest user rights(Bekele et al., 2015).

Over the years, a number of forest policies and legal instruments have been formulated and implemented in Ethiopia to address forestry-related challenges. The country has also adopted several international treaties and conventions related to sustainable management of its forest resources over the last three decades. However, forestry sector received renewed attention with the emergency of carbon financing schemes such as the REDD + (Reducing Emissions from Deforestation and Forest Degradation) initiative as manifested in the recognition of forestry sector as one of the key pillars of government strategy. The Government of Ethiopia (GoE) has been involved in the REDD ${ }^{+}$process since 2008 and is a participant country of the World Bank Forest Carbon Partnership Facility (FCPF). REDD ${ }^{+}$is a novel strategy introduced by UNFCCC as a measure to reduce greenhouse gas emissions and support developing countries in their efforts to reduce deforestation and forest degradation. The 
$\mathrm{REDD}^{+}$strategy has become very relevant for a low income countries like Ethiopia because of theirparticular vulnerability to climate change effects and low adaptive capacity.

This study adopted the Governance of Forests Initiative (GFI) framework (see: Davis et al., 2013) to assess the impacts of policies and legal framework on sustainable forest governance in Ethiopia. The GFI framework provides a comprehensive set of indicators that can be used to diagnose and assess the impacts of policies and other legal instruments on sustainable forest governance.

\section{Methodology and assessment framework}

\subsection{Methods of data collection}

Data for this study was collected through in-depth document review and interviews with key stakeholders.

\subsubsection{In-depth document review}

In-depth desk study/literature review was conducted on systematically selected documents relevant to forest landscape management and climate change and carbon emission reduction efforts such as $\mathrm{REDD}^{+}$initiatives. The document review was specifically focus on synthesizing and collating lessons relevant to the achievement of sustainable forest management objectives from the recent international, regional, and national assessments of forest tenure forms and level of security. Different regional, national, and international legal and policy instruments, which are relevant for forest landscape management, climate change and carbon emission reduction efforts were thoroughly examined. The review was conducted on relevant legal and policy documents as well as recent analytical work on Ethiopian forestry sector.

\subsubsection{Interviews with key stakeholders}

In addition to the systematic document review, in-depth interviews were conducted with key stakeholders and knowledgeable individuals to critically examine the de jure and de facto practices of forest policy arrangements and institutional settings of forest governance in Ethiopia. The interviewees were selected on the basis of their roles and experiences in the forest and related environmental governance issues in Ethiopia, including REDD ${ }^{+}$, PFM, and related programmes at national, regional and project levels. These interviewees included politicians/policymakers and bureaucrats working at different administrative levels (from national to woreda level), NGO and donor officials, consultants, academicians, research scientists, and representatives of CBOs.

\subsection{Assessment framework}

Governance of Forests Initiative (GFI) framework, which is developed by World Resources Institute (see Davis et al., 2013), is adopted to assess the legal and policy framework governing forest sector in Ethiopia. The GFI framework is one of the comprehensive tools used to diagnose and assess strengths and weaknesses of legal and policy arrangement governing forest sector. The GFI framework is field-tested in several countries like Cameroon, Brazil, and Indonesia and yielded useful results and practical lessons on how to design and collect forest governance data. The GFI framework was primarily designed to support civil society-led, evidence-based advocacy for forest governance reforms at national and sub-national levels. However, the GFI indicators are proved to be useful for many different types of applications at various scales. According to Davis et al. (2013) the scope of GFI application may include:

- Government agencies wishing to assess the effectiveness of policy implementation;

- Legislators seeking to identify priorities for legal reforms;

- Multi-stakeholder bodies aiming to build consensus about governance challenges;

- $\quad$ NGO watchdogs or oversight bodies seeking to monitor government performance;

- International organizations or donor agencies seeking to verify compliance with safeguards;

The GFI framework has been designed to be flexible and adaptable to support a customized assessment for multiple applications. Accordingly, by customizing the framework to our objectives, we assessed two main themes (forest tenure and forest management)under five key dimensions. Forest tenure isassessed under three key dimensions(forest tenure rights, tenure dispute resolution, andconcession allocation). Forest management is assessed under two key dimensions (forest legal and policy framework, and forest law enforcement).

In total, we assessed 26 sub-dimensions and134indictors both for forest tenure and forest management. A short description was included under each sub-dimension that summarizes the scope of the assessment, diagnostic question or objective, elements of quality or indictors that are the focus of data collection and help the user answer the diagnostic question in a structured manner. Indicator is used to describe a quantitative, qualitative, or descriptive attribute that, if assessed periodically, could indicate direction of change (e.g., positive or negative) in that attribute (Davis et al., 2013).

Scoring is the process of assigning quantitative values to indictors based on the data collected in order to concisely summarize assessment results or quickly identify strengths and weaknesses. At the design stage of this study, the indicators that describe the quantitative and qualitative, attributes of each sub-dimension were included in the semi-structured questionnaire prepared for community consultations and checklist designed for key informant interviews. Various stakeholders participated to answer the diagnostic questions designed to address 
each element of quality or indictor. These stakeholders include PFM members and other community members involved in various forms of forest management, private forest owners, experts and decision-makers working on forest and land administrations, law enforcement agencies from woreda to federal levels, and NGO officials and researchers working on land and forest related projects. Accordingly, a detailed and comprehensive data about forest tenure rights, tenure dispute resolution, and forest concession allocation were generated through community consultation, key informant interviews, and document review. Based on the evidence extracted from field notes, interview transcripts, document review and other relevant sources, researcher critically assigned score for each elements of quality or indictor. In assigning the score, researcher specifically focused on critically evaluating how well a specific element of quality has been met compared to the description or diagnostic question stipulated under each indictor. In doing so, the researcher double-check the assessment data before drawing conclusions about the quality of a specific indicator. Moreover, the researcher carefully employed the detailed guidance provided on WRI manual (see Davis et al. 2013), in translating assessment data into scores and drawing conclusions about elements of quality and indicators. Several strategies were also applied to minimize subjectivity and researcher's bias. First, we employed two data collection tools to triangulate and enrich information collected through different data collection techniques. Second, multiple stakeholders were involved ranging from different group of local communities, bureaucrats and decision-makers working at different levels and capacities, and independent experts from NGO and research organization. Third, instead of using the binary response (yes or no), which is commonly used in most WRI assessment, we adopted the four-tiered scoring system $(1=$ never, $2=$ sometimes, $3=$ often, 4=always ) developed in Brazil to capture the three key forest dimensions and adequately assign an accurate value to each indictor. Fourth, the three key forest tenure dimensions were assessed at 20 sub-dimensions and 102 indictors to minimize bias and enhance the precision of the score values. A short qualitative description is presented to justify the assigned score for each indictor and briefly describe the assumption behind the sore. Finally, multistakeholder forum will be carefully organized to review and validate the assessment results, which enhance the credibility and legitimacy of the report.

Therefore, following the experience of GFI assessment in Brazil, we consistently assigned quantitative values ranging from 1 to 4 denoting: $1=$ never, $2=$ sometimes, $3=$ often, $4=$ always. After calculating average score or cumulative performance, the quality of each sub-dimension is determined as: $1-1.5=$ very weak, $1.6-2.5=$ weak, $2.6-3.5=$ moderate, $3.6-4=$ strong. The consistency in assigning values is very important for ensuring the comparability of results across different indicators and through time.

\section{Results}

\subsection{Forest tenure rights}

Forest tenure rights refers to the entire bundle of forest-related property rights that may be held privately, communally, or by state, including right to access, right to use or withdrawal, right to manage, exclusion, alienation, right to compensation, and the right to security (Johnson, 2007). Stable tenure rights and the assurance that those rights will be protected, or disputed through due process, are essential for sustainable forest management. Local communities who depend on forests for daily subsistence and livelihood, and have a connection to forests over long periods of time, will take responsibility for better long-term care of the land and forest if they have control over most of the bundles of rights. Tenure rights govern the ability of forest owners and other landowners to acquire, manage, use, and dispose of their land and its products and services (Robinson et al., 2014). These rights are exclusive, but not absolute because landowners' tenure rights are generally bounded by limits on externalities, such as preventing soil and water pollution, or other relevant requirements to leave land in good condition for future generations, such as seed tree or tree planting requirements. Clear property rights are arguably the fundamental requirement for sustainable forest management, and a process to assign those rights, determine who controls and determines those rights, and a means to resolve disputes must be clear and accessible to all owners (Robinson et al., 2017).

In this study, the forest tenure rights dimension is analyzed from the perspectives of ten (10) sub-dimensions and fifty (50) indictors with the score ranging from strong to very weak. The cumulative performances of this dimension scored moderate. However, sub-dimensions like forest tenure adjudication in practice, support for rights-holders, and recognition and protection of forest tenure rights in practice showed weak performance. Particularly, information about forest tenure rights was evaluated as very weak and requires greater attention to improve the overall forest tenure system. This indicator evaluated whether the existing system comprehensively store information about the nature and spatial extent of tenure rights in forests in the form of database or website digitally or in hard copy. Such forest tenure records include holding titles, certificates, licenses, permits, or other contractual agreements defining the ownership or use rights of private individual, community, or the state. It also includes informal records such as community maps or other documents produced by individuals or communities to document their tenure claims. 


\section{Analysis on forest tenure rights}

\section{- Summary analysis on forest tenure rights}

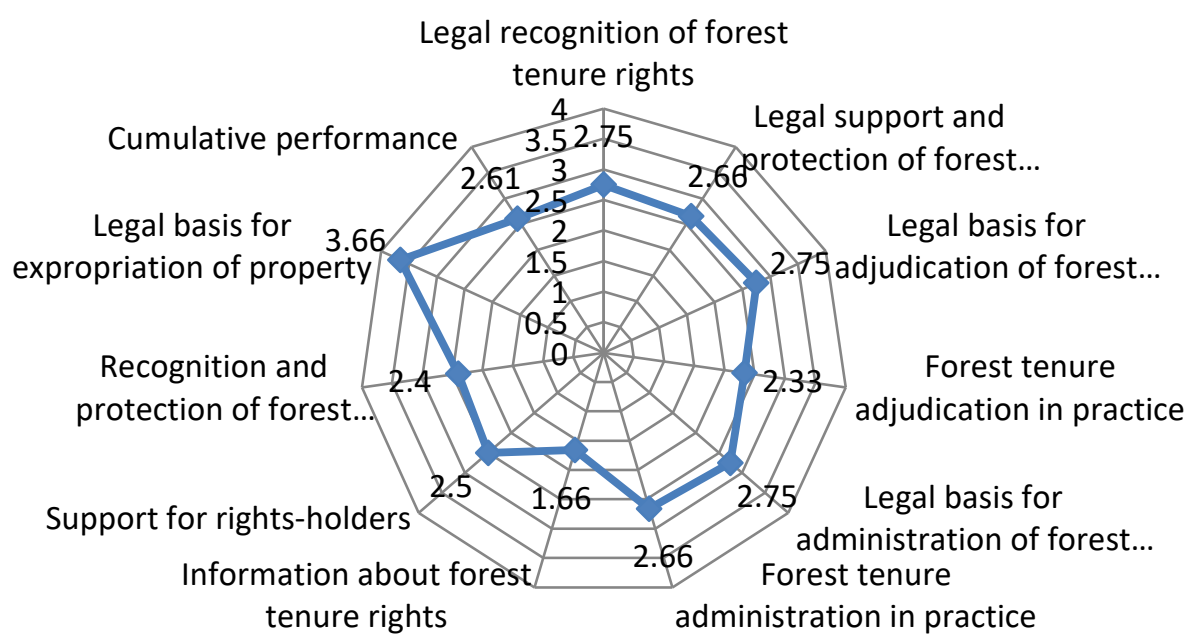

The current forest development, conservation and utilization proclamation No. 1065/2018 recognizes four forest tenure categories, namely, private, community forest, association, and state forests (Article 4). Recognition of four types of tenure categories is a significant positive step compared to the recently repealed forest proclamation (proc. No. 542/2007), which categorized forest ownership into state and private. Besides expanding forest tenure categories, the new forest proclamation further elaborated legally recognized buddle of rights for each tenure type. For example, the legally recognized buddle of rights for private forest (forest other than community or state forest, and developed on private or institutions' holding) according to the new forest development, conservation and utilization proclamation No. 1065/2018, Art 5 are:

- $\quad$ obtain certificate of title deed

- $\quad$ utilize or sell the forest products and ecosystem services including carbon to local or foreign markets

- transfer possession rights, however, the land holding cannot be sold and can be transferred only through inheritance to family members and can be leased, subject to restrictions on the extent and duration of leases (Rural Land Use and Administration Proc. No. 456/2005, Art 5/4 \& Art 8)

- $\quad$ get compensation in case of expropriation of possession for public interest

- $\quad$ conduct business by providing services as well as adding value to forest products

- $\quad$ free from land lease and any kind of tax for the first production period

- $\quad$ access to loan upon fulfilling appropriate requirements, however, no clear indication about the right to use the holding as a collateral.

The legally recognized buddle of rights for community forest (forest developed, conserved, utilized, and administrated by the community on its private or communal possession based on by laws and plans developed by the community, according to proc No. 1065/2018, Art 7 are:

- $\quad$ voluntarily engage in participatory forest management;

- $\quad$ obtain certificate of title deed;

- $\quad$ share benefits obtained from the forest;

- $\quad$ get priority to benefit from forest concession;

- $\quad$ get professional, technical, inputs, and legal services;

- $\quad$ utilize, sell, and add value to forest products;

- $\quad$ get compensation in case of expropriation of possession for public interest;

- $\quad$ exemption from any forest development income tax for two consecutive production period;

- $\quad$ access to loan upon fulfilling appropriate requirements; however, no clear indication about the right to use the holding as a collateral;

- $\quad$ no clear article on the right to transfer possession rights 
Communal land holding including forest land is also recognized by the 1995 constitution, rural land use and administration proc. No. 456/2005. Proclamation 456/2005, Article 2/12 defines the communal holding as rural land which is given by the government to local residents for common grazing, forestry and other social services. The constitutional articles that support communal forest land holding include: 1) freedom of association which could allow people to organize into forest use groups; 2) direct participation of the local people in all matters (which include forest management and sustainable utilization issues); and (3) joint ownership of land and other natural resources (which shall apply to forest resources).

The legally recognized buddle of rights for association forest (forest developed, conserved, utilized, and administrated by the associations established to develop forest), according to proc No. 1065/2018, Art 9, are:

- $\quad$ all rights and incentives bestowed for private forest developers are also granted for associations of forest developers upon registration with the appropriate government body;

free from any kind of tax for the first production year;

- $\quad$ access to a loan upon fulfilling the appropriate requirements; however, phrase 'appropriate requirements' is not clearly specified in the current proclamation;

The key steps to establish community or association forest involve: a) screening forest users who want to voluntarily engage in participatory forest management, b) delineating the forest boundary to be managed anddeveloping a forest management plan (FMP), and c) preparing a forest management agreement (FMA) that details roles and responsibilities of parties involved in forest management. The roles and responsibilities to be detailed in the FMA include: forest development, forest protection, forest harvesting, and forest monitoring. FMA also includes internal rules (bylaws) that define the day-to-day decision making process of the participating parties. The FMA is considered as a legally binding contract when it is signed between a community organization and a relevant government agency.

Although the approved FMA is considered as a legally binding contract, majority of local communities consulted in the course of this study claim additional paper documentation such as certificate of holding to proof their ownership and reduce the likelihood of losing the forest. Currently, the government of Ethiopia is implementing certification of common land in the name of groups using the common resources. The land certification process is advancing in the highland areas while in the pastoral areas, where vast communal range wooded lands exists, the registration and certification process is at piloting stage due to technical difficulties to identify and demarcate boundaries according to the customary use rights in the area. However, there are several initiatives by government and NGOs to implement communal land certification in pastoral areas like Borana lowlands using the customary range land management approach (interview with director of Rural Land Administration and Use Directorate in the MoANR, July 2018). The Ethiopian constitution recognizes the right of pastoralists in Article 40, sub-article 5, which states: "Ethiopian pastoralists have the right to free land for grazing and cultivation as well as the right not to be displaced from their own lands". The rural land administration and use proclamation (456/2005) confirms constitutional rights of pastoralists. The Oromia rural land administration and use proc. No. 130/2007, Art 6 stipulates that "any peasant or pastoralist, or semi pastoralists who has the right to use rural land shall have the right to use and lease on his holdings, transfer it to his family member and dispose property produced there on, and to sell, exchange and transfer the same without any time bound". Likewise the Oromia forest proclamation No. 72/2003, Article 6/1, states: "the state owned forest, patches of forests outside the boundary of the state forest may be handed over to organized local community based on the recommendation of study that suggest better forest management under community ownership". According to regulation No 122/2009, article 16, sub-article $3 \& 4$, besides the registered concession areas of OFWE, the enterprise shall administer demarcated and un-demarcated woodlands, highlands and lowland bamboo, incense and gum resources in the region; as well as open lands designated by the government for forest development purpose in accordance with the land use studies. Thus, in order to minimize the legal gap regarding forest designation and demarcation the Oromia Regional State Regulation No 122/2009, article 2, sub-article 1 defined state forest as: "any protection or production forest, high-forest or woodland, demarcated or non-demarcated forest, and also includes lowland and highland bamboo, incense and gum, and all owned by the Regional Government of Oromia".

In spite of the various laws that support communal resource management and access of local people to forest resources, there are huge gaps in the implementation of these rules in practice, particularly in accommodating the customary rights of local people to access the very resources they have been managing for ages. These created a feeling of hostility by the local people toward the forests. To overcome this long standing sense of insecurity, it is important to issue certificate of forest title deed to organized beneficiaries, which is believed to enhance sense of ownership and ensure tenure security. It is also imperative to strengthen the legal and administrative protection for organized community or associations by limiting the powers of government organs not to interfere with the day to day activities of community and clearly define the legal base for expropriation of possession for public interest. The scope of the phrase of 'public interest' shall be clearly defined to avoid ambiguities while interpreting and implement land expropriation.

As it exists now, the valid legal contract in the case of organized forest management group is Forest 
Management Agreement (FMA), which is classified in the Civil Code as administrative contracts. According to legal analysts, the government party has a special prerogative or an overriding power to modify or revoke the administrative contracts such as the forest management agreement even without consulting the other contacting party, in this case, organized local community. Different scholars explain that in a number of settings, the security of local forest management arrangements may be weakened by apparently wider powers on the part of the government to terminate the arrangement, or when the grounds for termination are poorly defined or vaguely spelled out (Lindsay, 2004; Alemayehu et al., 2015). Local communities are either reluctant to invest in such development activities or harvest rapidly from the common when they are not sure whether they can reap benefits from the final harvest. Gregersen (1988) indicates that local community responses to forestry related intervention is determined by strength of the institution to assure to all parties involved that they will reap the benefit, for instance, through provisions of reliable legal documents like certificate of title deed. Thus, for any forestry related interventions to be successful it must not only provide a realistic hope of significant benefits, it must install confidence that the rights to those benefits are secure and cannot be taken away arbitrarily. Because such confidence and positive sense of security will enhance community's compliance to the common rule, their commitment to the common goal and long-term plan and investment in the common recourses. Building confidence and sense of security particularly important for local community in the context of Ethiopia where the same government which denied their accesses to resources in the past, vested only usufruct rights but still maintained the ownership rights. Therefore, although building trust is not a one-time effort, all decisions taken with regards to joint forest management have to be legitimate, transparent and accountable, so that community members should develop confidence overtime that relevant laws are being upheld and their interest is being protected.

Another challenge in the context of communal tenure like PFM arrangement is the issue of boundary between users and non-users. The usual procedure during the establishment process of PFM is to assess the forest utilization pattern in order to identify primary and secondary users who would be allowed to become members of the new arrangement. However, membership selection criterion and delineating clear boundary between members and nonmembers is found to be problematic and prone to conflicts. Although in most cases households residing close to the forest resources are recruited as a PFM member, such approach creates disadvantage to the distant communities who also depend on the forest for several products. We observed strong objection and concern from non-members for being excluded from their customary use rights like getting forest-based fodder for their livestock, especially during dry periods in most PFM areas. Conflicts between members and non-members that led to violence and destruction of property were reported in most forest areas of the country, which will threaten the sustainability of the communal regime. The PFM members are also well aware of the fact that large groups of the community, particularly the youth are excluded from membership. Such conflicts can aggravate and endure over long periods if those who are excluded cannot find alternative livelihoods or other job opportunities. Moreover, in some areas the official principlesthatall members have equal rights and responsibilities is facing practical challenge on the ground where the already existing traditional arrangement allows some individual holdings in which a few family members own adjacent forest plots that constitute the entire forest block under the PFM arrangement. This is particularly evidenced in the coffee growing areas of the country. In those areas, members who have no traditional use rights are not allowed to harvest economically important forest products, such honey, coffee, and spices, and in general they are not perceived as legitimate 'owners' of forest plots. They are only allowed to use some forest products, such as firewood and farming materials, and other products for subsistence use. Moreover, in certain areashuge PFM members (more than sex hundred) organized in one user group, which is practically unmanageable. In these areas there are complaints that even non-community members including urban dwellers have been unfairly included in absentia. This issue should be further clarified and resolved to sustain the communal tenure system in the area.

It is important to clearly and fairly defined membership criteria and bundles of right for all members to minimize grievances build sense of ownership. In this regard the traditional forest tenure rights held by local community and other groups as customary tenure systems need to be officially recognized and clearly aligned with the statutory framework. It is necessary to develop a comprehensive guideline that supports multiple rights to coexist on the same plot of forest land. As a communal tenure arrangement, PFM shall limit the access or may even exclude non-members from accessing the forests under PFM regime. The regional and local government should devise mechanisms for non PFM members such as unemployed youth and those who have lost their customary access due to the establishment of the new system. The mechanisms to consider include encouraging value addition and value chain development where members and non-members are effectively linked in the commodity chains of legally harvested forest products. This will not only ensure equity but also enhance the productivity and benefits derived from forests the PFM regime.

\subsection{Tenure dispute resolution}

The forest tenure dispute resolution dimension is assessed under four sub-dimensions and 19 indictors with the 
score ranging from strong to weak. The cumulative performances of this dimension scored weak. The subdimensions of the legal basis for dispute resolution bodies is evaluated strong mainly because a number of legislations exist both at federal and regional state level that provide legal ground for dispute resolution process.

\section{Analysis on tenure dispute resolution}

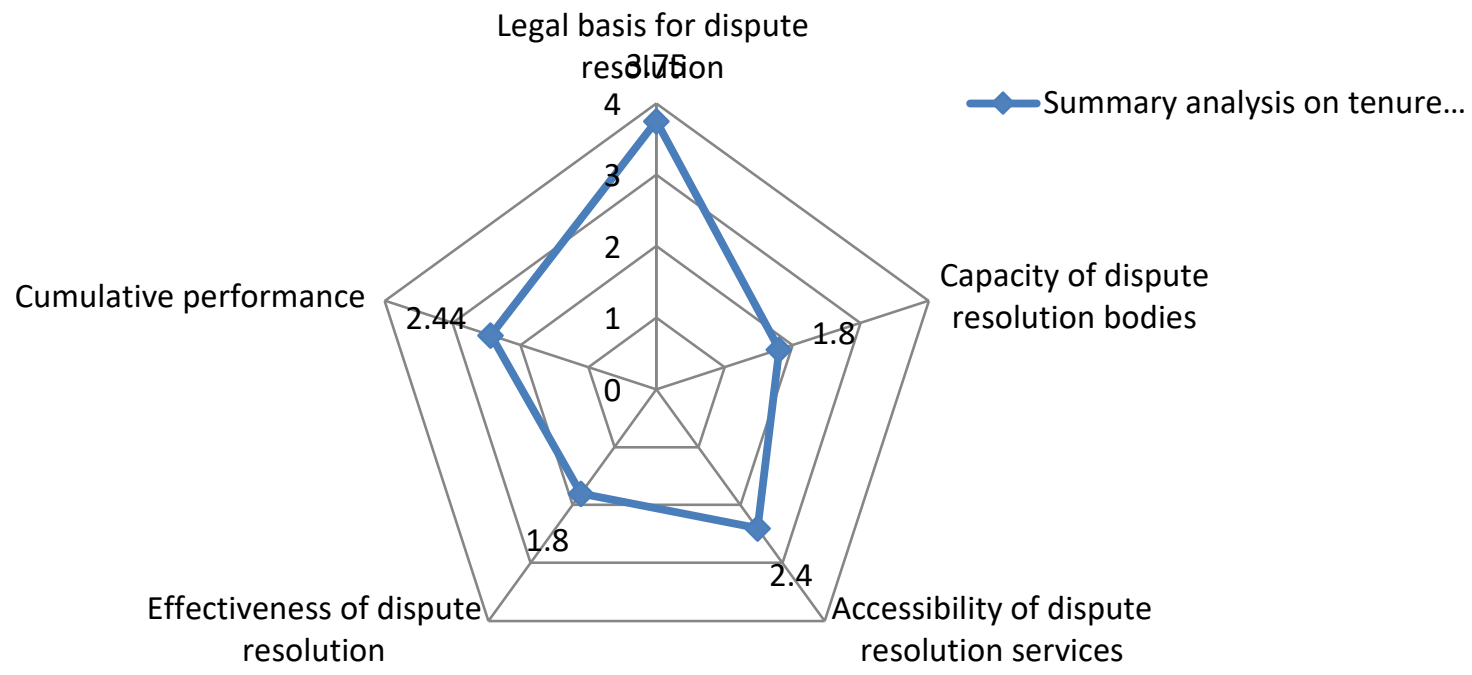

For example, the federal rural land use and administration proc. No. 456/2005 provides a guiding principle on dispute settlement mechanism. Article 12 of this proclamation stipulates that "where dispute arises over rural landholding right, effort shall be made to resolve the dispute through discussion and agreement of the concerned parties. Where the dispute could not be resolved by agreement, it shall be decided by an arbitral body to be elected by the parties or decided in accordance with the rural land administration laws of the region". The Oromia rural land administration and use proc. No. 130/2007 and regulation No. 151/2013 also detail clear procedure and institutional mandates for tenure dispute resolution bodies at different administrative levels and for different types of disputes. The latter proclamation also grants dispute resolution bodies adequate powers to deliver and enforce rulings and defines requirements and procedures to ensure the independence and impartiality of dispute resolution bodies (proc. No. 130/2007, Art 16/ 1 (a-j)). This proclamation also recognizes the legitimacy of community-based and customary dispute resolution systems by demanding dispute case to pass through arbitration elders. On the country, the new forest proclamation No. 1065/2018 paid inadequate attention to dispute resolution in forest tenure rights. However, the provisions of rural land administration and use proclamation also encompass forest tenure. Indictors like capacity of dispute resolution bodies, accessibility of dispute resolution services, and effectiveness of dispute resolution are evaluated as a weak and requires careful attention to improve the overall performances of forest tenure dispute resolution. For example, the capacity of dispute resolution bodies were assessed whether they have expertise in relevant tenure laws and practice alternative means of resolving disputes, such as mediation; and have access to sufficient financial and human resources to handle their case volume. The staff of law enforcement agencies that we interviewed in the various study woredas evaluated the judicial mechanism of resolving dispute as weak in terms of the availability of expertise and resources. The dispute resolution services through judicial mechanism are also evaluated as weak in terms of its accessibility, affordability and legal aid for citizens who cannot afford the litigation. The experts also pointed out that a lot of emphasis was given to resolve disputes through the courts of law in the current legal system of Ethiopia. However, in most cases court litigations spoor enmity between the contending parties and have severe adverse effects. Thus, legal experts recommend to prioritize resolving disputes through arbitration before resorting to the courts and to include such legal provisions in the administrative contracts and bylaws.

In most cases violation of forest tenure rights may lead to conflict and violence, in particular when the rights in question are limited in breadth and scope, too short in duration, sustain unresolved conflicts between formal state law versus informal/customary claims, and lead to overlapping and inadequate rights, etc. People with insecure rights are often removed from their land by force. And whenever forced evictions take place, violence is generally used both for enforcement and defense of the eviction. The informants highly criticized the judicial procedures as inaccessible, long procedural, and often costly. Key informants criticized, especially when presenting forest related offenses to district or woreda level court. They pointed out some reasons: first, the district woreda court is very far from average villagers and they have to pay their traveling and other associated costs for 
deliberating their legal cases at district level. Second, it takes a very long time until one case is decided. As a result, villagers often prefer to reconcile the matter at local level, regardless of the level of the offense. 'Rule breakers', villagers said, are cognizant of this costly and length judicial procedure and as a result they ignore the rules and undermine the mandate of forest management committee. The major offenses presented to district level court were storing and transporting forest product without holding evidence from the authority, performing illegal activities in the forest like making charcoal, permanently settling in the forest, clearing forest for agriculture, keeping domestic animal in the forest.

Key informants from forestry department added that even those cases which received decisions were not fair and compatible with the magnitudes of offense. They added that most of the penalties are trivial to offenders and it is much more profitable for them to keep on committing the same offenses even after covering the penalties. They pointed to situations in which several offenders were repeatedly presented to the district court for similar offenses. They further explained that this encourages free-riders and rent-seekers while discouraging rule followers. This is partly attributed to the absence of specialized jurisdictions dedicated for communal resource management and weak local level arbitration mechanism outside the formal lawsuit. According to the design principle (DP), which informed much of the process and structure of PFM in Ethiopia, rapid access to low-cost, local level legal arenas to resolve conflict among users and eternal claimants are a basic prerequisite for successful communal resource management system (see Ostrom, 1999, Alemayehuet al., 2015). The practical experience in most forest areas of the country, however, cannot fulfill this basic requirement. The empirical study by Kohler and Schmithüsen (2004) from comparative analysis of forest laws in 12 sub-Saharan African countries including Ethiopia also confirmed similar problem in the region. It is recommended that for successful communal resources management institutions to emerge in the region, the judicial systems should be easily accessed and effective enough to change the image of the wider public. This can be attained by encouraging community level dispute resolutions through arbitration that reduce costs and enable community members to use their time for other productive purpose. This requires revision of legal framework that recognizes and enforces decisions and agreements made through community level arbitration. The revised legal framework should also establishes clear procedures to build the capacity of community-based tenure dispute resolution bodies by providing training, legal materials working space. For example, the capacity building efforts for the community-based dispute resolution bodies can be strengthened by linking with the legal aid centers established by various universities in the country to provide legal support for poor and vulnerable groups.

\subsection{Concession allocation}

The forest concession allocation dimension is assessed under six sub-dimensions and 33 indictors. The scores of these indictors range from weak to very weak with cumulative performances scored as weak.

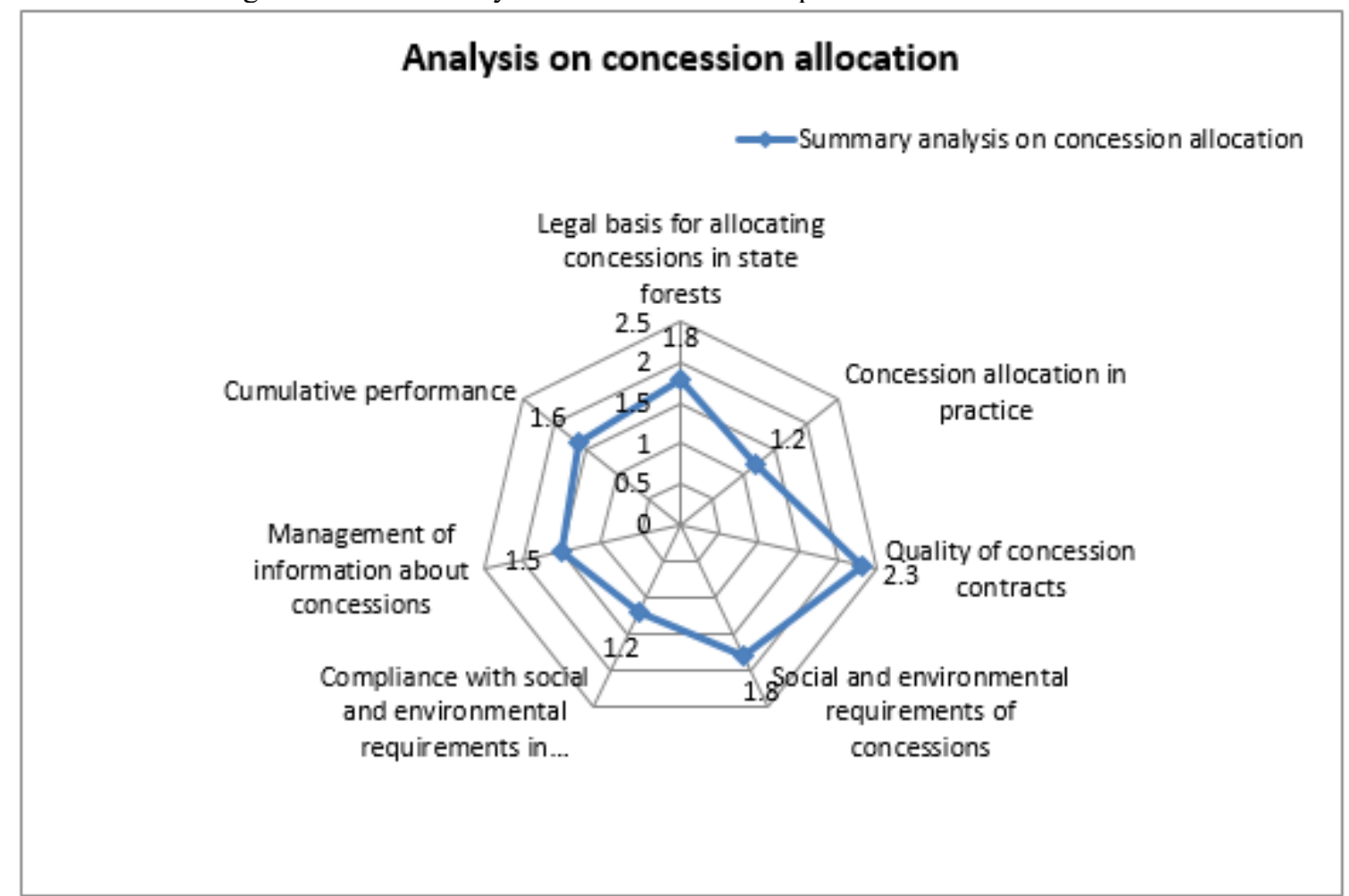

The new forest proclamation No. 1065/2018, article 2/10 defines forest concession as "a contract given to a 
person with legal standing to develop, conserve or to utilize a given state forest for a defined period of time". According to this definition, concessions are usually intended for business enterprise and it is not clear if this applicable for community based forest management groups like PFM. The same proclamation article 7/1/d guarantee community forest developers the right to get priority to benefit from the forests concession given by the government. Therefore, detail regulation and directives are required to clarify whether community forest management is considered as concession contract and make clear the duration of the contract considering the long gestation period of harvesting forest products. Although concession allocation for agricultural investment is very common, private investment in forest sector is limited in Ethiopia. This analysis focused on the case of Oromia Forest and Wildlife Enterprise (OFWE) that administer and manage most Oromia's forest resources through concession. The legal basis for allocating forest concessions in is evaluated as weak. A number of reasons were identified during the analysis: 1) there is no comprehensive legal framework that defines transparent and competitive process for allocating forest concessions including public disclosure of information relating to the allocation process; 2) technical requirements and minimum qualifications for application is not clearly defined; 3 ) existing tenure claims and claimants were not properly identified and addressed prior to allocating concession, for example, organized local community were managing several forest areas in Oromia under PFM arrangement prior to the allocation of those forests to OFWE and the rights and duties of these two claimants were not properly addressed. The evaluation concerning the transparency and accountability of forest concession allocations in practice is very weak mainly because indictors such as legal compliance, respect of existing rights, anticorruption measures, public disclosure of information about the allocation process, and public consultation are very weak in practice. For example, although the legal framework including the constitution (article 43/2) requires public consultation prior to implementing any development initiatives, in practice, local community have minimum opportunities to participate and influence the concession allocation process even when the interventions have significant social or environmental impacts. The mechanisms and practice to conduct proactive impact assessment, mitigation and monitoring of social and environmental impacts due to concession contracts is very weak. Particularly, there is huge gap concerning monitoring of concession-holder's compliance with contractual provisions and taking corrective measures when negative social or environmental impacts are detected. The information management system concerning concession allocation and their operations is also very weak. Accurate and up-to-date information and records that contain comprehensive legal and spatial information about forest concession are expected to be maintained centrally both at regional state and federal level and freely accessible by the public. However, in practice, accessing well-organized information on forest concession is challenging.

\subsection{Forest legal and policy framework}

Forest legal and policy framework dimension analyzes key policies, laws, and regulations that definethe social, environmental, and economic objectives of forestry sector. It analyzed under three sub-dimensions and 17 indictors.

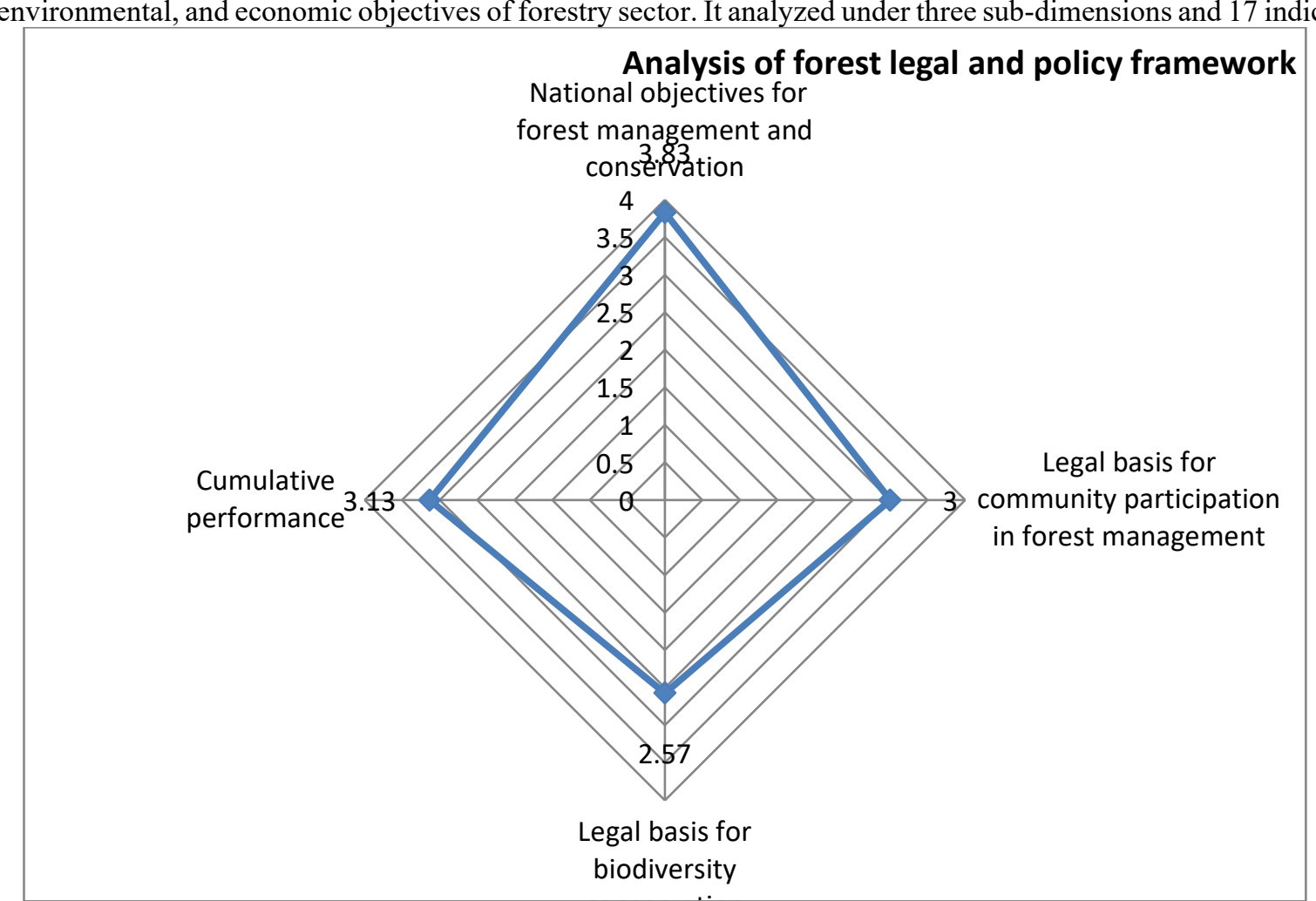


The cumulative performances of this dimension scored moderate. The sub-dimensions of the national objectives for forest management and conservation is evaluated strong mainly because a number of legislations exist that show that objectives in forest policy and law are consistent with national development goals and strategies. For example, the new forest Conservation and Utilization proclamation No. 1065/2018 is consistent with the national priorities and development plans such as GTP II CRGE, and National REDD ${ }^{+}$strategy. The subdimension that concerns on the legal basis for community participation in forest management is evaluated moderate. This is mainly because both 2007 forest policy and 2018 forest proclamation require public participation in forest management planning and operations. However, the evaluation is moderate because participation requirements are not sufficiently strong to ensure that community feedback is reflected in management decisions from the early stages of planning. On the other hand, sub-dimension that concerns on the legal basis for biodiversity conservationis evaluated weak mainly because of the gap in terms of establishing a national database of biodiversity and genetic resources, which may be useful for a national biodiversity monitoring system to track species, habitats, ecological communities, and genetic diversity. Although there are rules that stipulate penalties for failure to comply with measures to protect biodiversity, these penalties are not properly tied to the nature and severity of the violation.

\subsection{Forest law enforcement}

Forest law enforcement dimension analyzes the efforts to enforce and promote compliance with forest laws and regulations, including the detection of illegal activities, prosecution of offenders, and application of sanctions. It is analyzed under three sub-dimensions and 15 indictors.

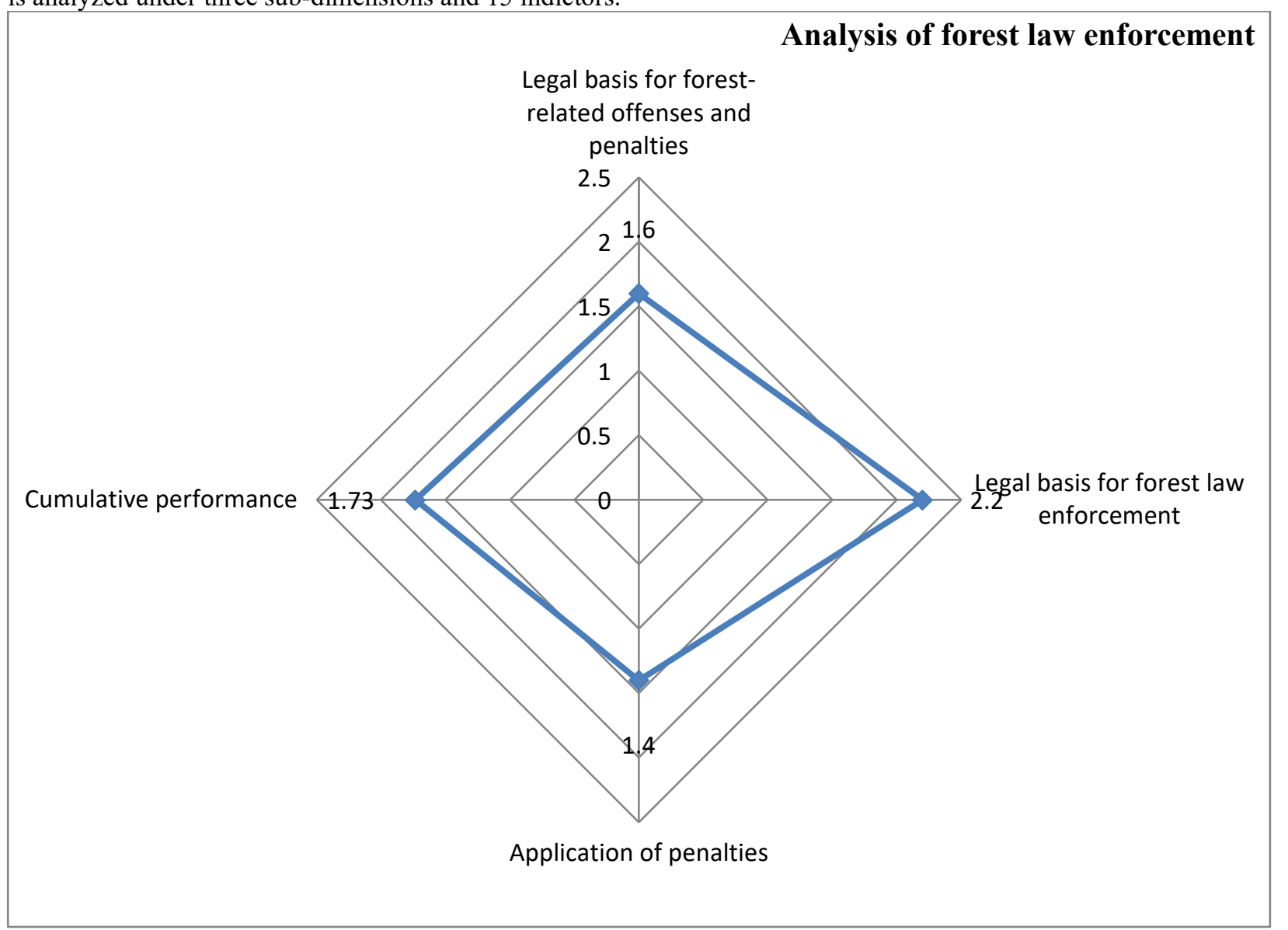

The cumulative performance of this dimension is weak. Two of the sub-dimensions namely legal basis for forest-related offenses and penalties; and legal basis for forest law enforcement scored weak. The third subdimension - application of penalties - scored very weak. Some of the key reasons for the weak performance of this dimension are:

- There is lack of clarity in the legal framework to provide how the severity of a penalty for a forest crime is determined. For example, there is limitation in the legal framework in providing parameters or guidance for how fine or jail time is determined in practice, which could minimize the power of officials to reduce fines or waivejail time without justification.

- $\quad$ Although the legal framework defined major types of forest infractions, those definitions are stipulated 
only at proclamation level and not properly translated into regulations, directives and guidelines. For example, there is lack of directive or guideline that defines a clear set of procedures or protocols for pursuing and documenting forest law enforcement investigations.

- The legal framework is not clear in defining compensatory measures for forest infractions. For example, the new forest law is not clear on how to pay fines for restoration in cases of illegal harvesting or forest clearing.

- The legal framework does not clearly define the roles and mandate of institutions in a way that create coherent and avoid conflicts or overlaps.

- Very weak monitoring of compliance with penalties issued for forest crimes by relevant institutionand weak follow up in terms of taking further legal action in cases of noncompliance.

- There is a weak practice of routinely documenting forest crimes and publicly disclosing information about penalties and their state of compliance.

\section{Conclusions and recommendations}

\subsection{Conclusions}

This study assessed the policies and legal frameworks governing forestry sector in Ethiopia in order to better understand the conflicting and unbalanced sectoral policies, poor institutional coordination, and weak law enforcement. We adopted the GFI (Governance of Forests Initiative) framework developed by World Resources Institute that works to promote policies and practices that strengthen forest governance to support sustainable forest management and improve local livelihoods (Davis et al., 2013). The GFI framework provides a comprehensive set of indicators that can be used to diagnose and assess strengths and weaknesses of legal, policy, and institutional framework governing forest tenure and forest management. We analyzed 26 sub-dimensions and 134 indictors both for forest tenure and forest management key themes. Through this comprehensive analysis we identified which forest tenure and management issues scored weak and very weak that requires serious corrective measures to improve forest governance in Ethiopia. Table 1 presents forest tenure and management sub(dimensions) that scored weak and very weak and require policy actions.

\begin{tabular}{|c|c|c|}
\hline Sub-(dimensions) & Score & Issues require attention and policy action \\
\hline \multicolumn{3}{|l|}{ Forest tenure rights } \\
\hline $\begin{array}{l}\text { Forest tenure } \\
\text { adjudication in practice }\end{array}$ & Weak & $\begin{array}{l}\text { Consultation of claimants, support for vulnerable claimants, fairness of } \\
\text { outcomes, and access to effective redress mechanisms if rights are not } \\
\text { respected }\end{array}$ \\
\hline $\begin{array}{l}\text { Information about forest } \\
\text { tenure rights }\end{array}$ & Weak & $\begin{array}{l}\text { How information about forest tenure rights is maintained, } \\
\text { comprehensiveness, accuracy, accessibility of information and inclusion of } \\
\text { informal rights }\end{array}$ \\
\hline $\begin{array}{l}\text { Support for rights- } \\
\text { holders }\end{array}$ & Weak & $\begin{array}{l}\text { Rights holders' access to capacity building services and technical support } \\
\text { and additional legal, technical, and financial assistance for vulnerable } \\
\text { rights-holders }\end{array}$ \\
\hline $\begin{array}{l}\text { Recognition and } \\
\text { protection of forest } \\
\text { tenure rights in practice }\end{array}$ & Weak & $\begin{array}{l}\text { Demarcation of forest of boundaries, law enforcement to quickly and fairly } \\
\text { address infringements of rights, the inconsistency and conflict between } \\
\text { customary and statutory forest tenure systems on the ground }\end{array}$ \\
\hline \multicolumn{3}{|l|}{ Tenure dispute resolution } \\
\hline $\begin{array}{l}\text { Capacity of dispute } \\
\text { resolution bodies }\end{array}$ & $\mathrm{We}$ & $\begin{array}{l}\text { Availability of tenure expertise in relevant tenure laws and practices, } \\
\text { expertise in alternative dispute resolution such as mediation, access to range } \\
\text { of evidence, financial and human resources to handle tenure dispute cases }\end{array}$ \\
\hline $\begin{array}{l}\text { Accessibility of dispute } \\
\text { resolution services }\end{array}$ & Weak & $\begin{array}{l}\text { Accessibility and affordability of dispute resolution services, availability of } \\
\text { legal aid or free legal services for peoples who cannot afford court litigation }\end{array}$ \\
\hline $\begin{array}{l}\text { Effectiveness of dispute } \\
\text { resolution }\end{array}$ & Weak & $\begin{array}{l}\text { Evidence base for rulings, timeliness, fairness, enforcement, and disclosure } \\
\text { of rulings }\end{array}$ \\
\hline \multicolumn{3}{|l|}{ Concession allocation } \\
\hline $\begin{array}{l}\text { Legal basis for allocating } \\
\text { concessions in state } \\
\text { forests }\end{array}$ & Weak & $\begin{array}{l}\text { Defining open and competitive process for allocating concessions, } \\
\text { anticorruption measures, clearly defining the minimum qualifications and } \\
\text { technical requirements for application }\end{array}$ \\
\hline $\begin{array}{l}\text { Concession allocation in } \\
\text { practice }\end{array}$ & $\begin{array}{l}\text { Very } \\
\text { weak }\end{array}$ & $\begin{array}{l}\text { Compliance with relevant laws and regulations, identifying and addressing } \\
\text { issues related of existing tenure claims, public consultation and disclosure } \\
\text { of information, minimizing administrative discretion and opportunities for } \\
\text { corruption during concession allocation }\end{array}$ \\
\hline
\end{tabular}


Quality of concession Weak

Social and environmental requirements of concessions

Compliance with social and environmental requirements in concession contracts

Management

of Very information about weak concessions

Weak

Very weak contracts

Comprehensive legal contracts and agreement including all technical requirements, administrative procedures and obligations of contract-holder in terms of financial, environmental protection and social aspects

Comprehensive concession contracts that require environmental and social impact assessment, community engagement, mitigation, monitoring and corrective measures if negative social and/or environmental impacts are detected

Conducting and publically disclosing social and environmental impact assessments, establishing equitable social agreements with local communities, putting in place appropriate avoidance and mitigation measures, regular monitoring, reporting, and taking corrective measures when negative social or environmental impacts are detected

Establishing central database to store and managing accurate and up-to-date information that contain comprehensive legal and spatial information about forest concession

\section{Forest legal and policy framework and Forest law enforcement}

Legal basis for Weak

biodiversity conservation

Legal basis for forestrelated offenses and penalties

Weak

Establish a national database of biodiversity and genetic resources that should be part of a national biodiversity monitoring system to track species, habitats, ecological communities, and genetic diversity

Forest-related offenses and penalties should be clearly defined in the legal framework and they should be differentiated by the nature and severity of the crime. The financial penalties for forest infractions should be routinely updated and compensatory measures need to be clearly defined in the legal framework.

Legal basis for forest law Weak Directives or guideline is needed to clearly define procedures that govern enforcement forest law enforcement investigations, frequency of law enforcement monitoring, handling of evidence, and reporting of infractions.

Application of penalties Very Law enforcement agencies including judges and prosecutors need to get formal training on the forest legal framework. Forest related penalties need to be consistent with the rules in the legal framework and the penalties should be proportional to the crime and concerned institution should monitor the level of compliance and enforcement of penalties.

\subsection{Recommendations}

- Information about forest tenure rights such as records of holding titles or certificates, and other contractual agreements, which define ownership or use rights are very weak in Ethiopia and these require greater attention to improve the overall forest tenure system.

- Strengthen the legal and administrative protection for organized community by limiting the powers of government organs not to interfere with the day to day activities of community and clearly define the legal base for expropriation of possession for public interest. The scope of the phrase of 'public interest' shall be clearly defined to avoid ambiguities while interpreting and implement forest land expropriation.

- It is vital to clearly and fairly defined membership criteria and bundles of right for all PFM members to minimize grievances and build sense of ownership. As a communal tenure arrangement, PFM shall limit the access or may even exclude non-members from accessing the forests under PFM regime.

- The traditional forest tenure rights held by local community and other groups as customary tenure systems need to be officially recognized and clearly aligned with the statutory framework.

- It is necessary to develop a comprehensive guideline that supports multiple rights to co-exist on the same plot of forest land.

- The judicial systems should be easily accessible and effective enough for successful performances of communal resources management institutions in Ethiopia. This can be partly achieved by encouraging community level dispute resolutions through arbitration that reduce costs and enable community members to use their time for other productive purpose. It also requires revision of legal framework that recognizes and enforces decisions and agreements made through community level arbitration.

- Accurate and up-to-date information and records that contain comprehensive legal and spatial information about forest concession allocation and their operations should be maintained centrally both at regional state and federal level and should freely accessible by the public. 


\section{References}

Alemayehu, N. Ayana, Vandenabeele, N., Arts, B. (2015). Performance of participatory forest management in Ethiopia: institutional arrangement versus local practices. Critical Policy Studies, DOI: 10.1080/19460171.2015.1024703.

Davis, C. Williams, L., Lupberger, S., and Daviet, F. (2013). Assessing Forest Governance: The Governance of Forests Initiative Indicator Framework. World Resources Institute (WRI),

Gregersen, H. (1988). People, Trees and Rural Development. Journal of forestry: 22-30.

Johnson, D. R. (2007). Reflections on the Bundle of Rights. Vermont Law Review Vol. 32:247.

Kohler, V. and Schmithüsen, F. (2004). Comparative Analysis of Forest Laws in Twelve Sub-Saharan African Countries. FAO Legal Papers online No. 37(available at http://www.fao.org/legal/pub-e.htm)

Lindsay, J. (2004). Legal Frameworks and Access to Common Pool Resources. Development Law Service, FAO Legal papers online No. 39.

Ostrom, E. (1999). Institutional Analysis, Design Principles, and Threats to Sustainable Community Governance and Management of Commons. In: Berge, E. and Christian, N. S. ( eds), Law and the Governance of Renewable Resources: Studies from Northern Europe and Africa. Oakland, CA, CS Press: 27-53.

Robinson, B.E., Holland, M.B. and Naughton-Treves, L. (2014). Does secure land tenure save forests? A metaanalysis of the relationship between land tenure and tropical deforestation. Glob. Environ. Chang., 29, 281293.

Robinson, B.E, et al. (2017). Incorporating Land Tenure Security into Conservation.Conservation Letters, June 2017, 00(0), 1-12.

Schlager, E and Ostrom, E. (1992). Property-rights regimes and natural resources: A conceptual analysis. Land Economy 68(3) p.249-262.

UNEP. (2017). The contribution of forests to national income in Ethiopia and linkages with REDD ${ }^{+}$. United Nations Environment Programme: Nairobi. 